\title{
EL LIDERAZGO Y LA GOBERNANZA \\ COLABORATIVA EN PROYECTOS EDUCATIVOS COMUNITARIOS
}

\author{
LEADERSHIP AND COLLABORATIVE \\ GOVERNANCE OF EDUCATIONAL PROJECTS IN THE COMMUNITY
}

\author{
LIDERANÇA E GOVERNANÇA \\ COLABORATIVA DA PROJETOS DE EDUCAÇÃO COMUNITARIA
}

\author{
Jordi Díaz-Gibson, Mireia Civís Zaragoza y Elena Carrillo Álvarez \\ UNIVERSIDAD RAMÓN LLULL, ESPAÑA
}

Meritxell Cortada Pujol

UNIVERSIDAD DE VIC, ESPAÑA

\begin{abstract}
RESUMEN: Introducción y objetivos: En el contexto socioeconómico actual la colaboración entre organizaciones educativas y sociales de la comunidad supone un activo clave para la mejora de los resultados educativos. El presente artículo profundiza en el liderazgo de estrategias colaborativas en el ámbito escolar y educativo para gobernar de forma exitosa proyectos socioeducativos de ámbito comunitario. De este modo, describe las estrategias necesarias para liderar dichos proyectos, así como las estructuras de toma de decisiones requeridas para sacar el máximo rendimiento a la colaboración interorganizacional. Metodología y tratamiento de datos: Para ello se toma como referencia el caso de Barcelona (España), donde existe una destacada tradición de colaboración comunitaria mediante el desarrollo de Redes Socioeducativas (RS). El estudio lleva a cabo un análisis de contenido de 30 entrevistas realizadas a profesionales experimentados en el liderazgo y el gobierno de RS de éxito. Resultados y discusión: Los resultados muestran un modelo de liderazgo dirigido a tejer alianzas a nivel comunitario, donde los líderes pretenden establecer sinergias entre las diferentes instituciones y servicios mediante la conexión cualitativa de los diferentes profesionales, generando confianza entre los mismos y fomentando la discusión, el consenso y la innovación. Además, los resultados subrayan la existencia de espacios específicamente diseñados para la toma de decisiones colaborativas, que van de más representativos - donde se deciden cuestiones generales o estratégicas-, a más operativos - donde se discuten cuestiones técnicas y de acción de proyecto-. Los resultados subrayan la importancia de equilibrar representatividad y operatividad para la efectividad en el gobierno de la red. Finalmente, se constata la existencia de 3 modelos diferenciados de gobernanza de la red, resaltando la importancia de adoptar el propio modelo a las características y necesidades de cada programa.
\end{abstract}


PALABRAS CLAVE: Redes Socioeducativas; liderazgo educativo; gobernanza socioeducativa; interdisciplinariedad; colaboración.

ABSTRACT: Introduction and objectives: In the current economic context collaboration between educational and social organizations in the community is a key asset for improving educational outcomes. This article intends to describe the strategies needed to lead collaborative projects in a community level, so as the structures of decision-making required to make the most of inter-organizational collaboration. Methodology and data processing: This paper looks at the case of Barcelona (Spain), where there is an outstanding tradition of community collaboration and successful experiences of Educational Networks (EN). The study conducted a content analysis of 30 interviews with experienced professionals in leadership and governance of successful EN. Results and discussion: Results show a leadership model aimed at building alliances at the community level, where leaders seek synergies weaving between different institutions and services by qualitatively connecting different professionals, building trust between them and encouraging discussion consensus and innovation. Moreover, the results highlight the existence of spaces designed specifically for collaborative decision making, ranging from more general or representative -where strategic issues are decided- to more technical and operational -where action project issues are discussed-. The results underline the importance of balancing between professional representation and action to achieve project effectiveness. Finally, the existence of 3 different models of network governance is found, highlighting the importance of adopting the model to the characteristics and needs of each program.

KEY WORDS: Educative Governance Networks, educational leadership, governance, interdisciplinarity, collaboration.

RESUMO: Introdução e Objetivos: No atual contexto socioeconômico colaboração entre as organizações da comunidade educacional e social é um elemento fundamental para a melhoria dos resultados escolares. Este artigo explora a liderança de estratégias de colaboração na escola e na educação para governar projetos de campo a nível comunitário com sucesso sócio. Assim, descreve as estratégias necessárias para levar esses projetos, bem como as estruturas de tomada de decisões necessárias para obter o máximo de colaboração interorganizacional. Metodologia e processamento de dados: Este se olha para o caso de Barcelona (Espanha), onde há uma tradição notável de colaboração da comunidade através do desenvolvimento de Sócio Networks (RS). O estudo realizou uma análise de conteúdo de 30 entrevistas com profissionais experientes na liderança e governança de RS sucesso. Resultados e discussão: Os resultados mostram um modelo de liderança que visa a construção de alianças a nível comunitário, onde os líderes buscam tecer sinergias entre as diferentes instituições e serviços por qualitativamente diferente ligação profissional, a construção de confiança entre eles e debate animador consenso e inovação. Além disso, os resultados destacam a existência de espaços projetados especificamente para tomada de decisão colaborativa, que vão desde geral ou -onde questões mais representativos estratégicas- são decididas, mais operacional, em que as questões técnicas e de projeto de ação são discutidos. Os resultados sublinham a importância de equilibrar a representação e efetividade operacional para a rede do governo. Finalmente, observamos a existência de três diferentes modelos de governação em rede, destacando a importância de se adotar o modelo com as características e necessidades de cada programa em si.

PALAVRAS-CHAVE: As redes sociais; liderança educacional; governança sócio; interdisciplinaridade; colaboração.

[ 60 ] JORDI DíAZ-GIBSON, MIREIA CIVÍS ZARAGOZA, ELENA CARRILLO ÁLVAREZ Y MERITXELL CORTADA PUJOL SIPS - PEDAGOGIA SOCIAL. REVISTA INTERUNIVERSITARIA [1139-1723 (2015) 26, 59-83] TERCERA ÉPOCA 


\section{Introducción}

El sistema educativo español afronta en la actualidad el complicado reto de evolucionar en un contexto de crisis socio-económica y decrecimiento de los recursos públicos. Este hecho supone una tensa y compleja realidad en tanto que los recortes en el presupuesto público y el consiguiente malestar de la comunidad educativa conviven con la exigencia social de hacer frente a grandes retos educativos, tales como la mejora de los resultados académicos de los estudiantes; la inclusión de alumnado con necesidades educativas especiales; la adaptación pedagógica a los cambios sociales promovidos por la revolución tecnológica; o la enseñanza de lenguas extranjeras en un mundo cada vez más globalizado, entre otros.

Ante este escenario, hoy más que nunca el liderazgo educativo aborda el complejo reto de generar sentido, reunir compromisos y construir proyectos educativos sólidos. Si bien el gobierno y el liderazgo de las escuelas son siempre funciones determinantes en el éxito escolar (Coronel, 2003; González, 2003), en la actualidad el liderazgo educativo va más allá de las escuelas y se advierte como uno de los temas más críticos y urgentes de la agenda educativa tanto en nuestro país como a nivel internacional (Bolívar, 2010; Carpenter et al., 2010; Miller, 2008; Ministerio de Educación y Ciencia, 2010). En este contexto, tanto la función de liderazgo como el propio equipo de gobierno de las organizaciones educativas tienen el reto inmediato de sacar el máximo rendimiento de los recursos existentes.

La optimización de los recursos disponibles se convierte en un elemento clave para la efectividad de los centros educativos. En este sentido, emerge la necesidad de buscar conexiones y sinergias tanto a nivel intraescolar como extraescolar o comunitario, subrayando la vertiente relacional y colaborativa del liderazgo educativo. Dichas sinergias pretenden por un lado obtener el máximo beneficio del capital humano de la propia organización, y por otro ampliar el capital humano y social buscando alianzas con el entorno socioeducativo próximo (Castiñeira, 2011; Daly, 2010; Longo, 2008, Mandell \& Keast, 2009; Miller, 2008).

En las últimas décadas el concepto de liderazgo educativo ha evolucionado claramente desde con-

\section{Introduction}

The Spanish education system is currently facing the complex challenge of evolving in a context of socioeconomic crisis and decrease in public resources. This fact represents a tense and complex reality as cutbacks in public budgets and the resulting discomfort among the educational community occur together with the social demand of facing great educational challenges, such as improving the students' academic results; inclusion of pupils with special educational needs; pedagogic adaptation to social changes caused by the technological revolution; or teaching foreign languages in a more and more globalized world, among others.

In view of this scenario, today more than ever, educational leadership is facing the complex challenge of generating sense, gathering commitments, and constructing sound educational projects. Even though the government and leadership of schools are always determining functions in school success (Coronel, 2003; González, 2003), at present educational leadership goes beyond schools and is considered one of the most critical and urgent issues in the educational agenda both in our country and at an international level (Bolívar, 2010; Carpenter et al., 2010; Miller, 2008; Spanish Ministry of Education and Science, 2010). In this context, both the leadership role and the governing team of educational organizations have the immediate challenge of taking full advantage of existing resources.

Optimizing available resources becomes a key element for effective educational centres. In this respect, the need to find connections and synergies emerges both at an intra-school and extra-school or community level, thus highlighting the relational and collaborative side of educational leadership. These synergies are aimed at getting the maximum benefit from the human capital of the organization, on the one hand, and enlarging this human and social capital by looking for alliances with the close socio-educational environment, on the other (Castiñeira, 2011; Daly, 2010; Longo, 2008, Mandell \& Keast, 2009; Miller, 2008).

In the last few decades, the concept of educational leadership has clearly evolved from more instructive concepts to more distributive concepts (Barnett \& McCormick, 2012; Bolívar, López-Yáñez, 
cepciones más instructivas a concepciones más distributivas (Barnett \& McCormick, 2012; Bolívar, López-Yáñez \& Murillo, 2013; Murillo, 2006). En este sentido, existe una amplia literatura respecto a una concepción del liderazgo educativo dirigido a aprovechar en mayor medida las capacidades del equipo docente, entendiendo que un liderazgo excesivamente centralizado desaprovecha el capital humano existente en la organización (Barnett \& McCormick, 2012; García, 2011; Lopez \& Lavié, 2010; Stewart, 1997).

Por otro lado, no son tantos los trabajos que profundizan en un liderazgo capaz de tejer sinergias a nivel extraescolar y comunitario. En los últimos años la complejidad de las problemáticas sociales y la falta de recursos en comunidades desfavorecidas ha dado lugar a casos de buenas prácticas colaborativas entre diferentes organizaciones socioeducativas. Estos proyectos educativos de ámbito comunitario son conocidos en nuestro territorio como Redes Socioeducativas (RS), dónde las escuelas y los agentes educativos y sociales de la comunidad colaboran en la construcción de una estrategia o proyecto compartido entorno a objetivos educativos comunes. Las RS han alcanzado una presencia notoria a nivel internacional obteniendo resultados educativos significativos (Miller, Díaz-Gibson, Miller-Balslev \& Scanlan, 2012; Carpenter et al, 2010; Tough, 2008; Ubieto, 2012).

Así, entendemos que las RS asumen un papel relevante en el desarrollo de un enfoque de liderazgo y gobierno colaborativo a nivel comunitario y por tanto, el estudio de buenas prácticas de RS en nuestro país puede describir algunas de las condiciones óptimas y necesarias para liderar en el contexto educativo actual. El presente trabajo se plantea una única pregunta de investigación: ¿Cómo pueden las organizaciones educativas de la comunidad liderar procesos de colaboración para la mejora de su impacto? De esta manera se pretende aportar estrategias para la mejora de la eficiencia educativa de las escuelas y otros agentes socioeducativos mediante la puesta en marcha de proyectos educativos colaborativos de alcance comunitario. Con este foco, el artículo ahonda en los conceptos de liderazgo y gobierno de las $\mathrm{RS}$, y pretende describir tanto las habilidades necesarias para liderar en entornos colaborativos, como las estructuras de toma
\& Murillo, 2013; Murillo, 2006). In this respect, there is a large body of literature about a concept of educational leadership aimed at taking greater advantage of the teaching staff's capacities, thus understanding that excessively centralized leadership wastes the human capital existing in the organization (Barnett \& McCormick, 2012; García, 2011; Lopez \& Lavié, 2010; Stewart, 1997).

On the other hand, there are not many studies focusing on a type of leadership that can create synergies at the extra-school and community level. In the last few years, the complexity of social problems and the lack of resources in disadvantaged communities have led to cases of good collaborative practice among different socio-educational organizations. These community-based educational projects are called Educational Collaborative Networks (ECN) in our country, where schools and educational and social agents of the community collaborate in the construction of a strategy or shared project around common educational goals. The ECNs have reached a notorious presence at an international level, obtaining significant educational outcomes (Miller, DíazGibson, Miller-Balslev, \& Scanlan, 2012; Carpenter et al., 2010; Tough, 2008; Ubieto, 2012).

Thus, we understand that the ECNs adopt a relevant role in the development of an approach to leadership and collaborative governing at a community level and, therefore, the study of good ECN practices in our country can describe some of the optimum and necessary conditions to lead in the current educational context. This paper proposes a single research question: How can the educational organizations in the community lead collaboration processes to improve their impact? In this sense, we aim at contributing with strategies to improve the educational efficiency of schools and other socioeducational agents by setting up community-wide collaborative educational projects. With this approach, the article delves into the concepts of leadership and governing of ECNs and aims at describing both the skills needed to lead in collaborative environments and the decision-making structures required to take full advantage from interorganizational collaboration. To do so, the study is based on the case of the city of Barcelona, which has a renowned tradition in community collaboration among educational and social entities and ins-

[ 62 ] JORDI DÍAZ-GIBSON, MIREIA CIVÍS ZARAGOZA, ELENA CARRILLO ÁLVAREZ Y MERITXELL CORTADA PUJOL 
de decisiones requeridas para sacar el máximo rendimiento a la colaboración interorganizacional. Para ello, el estudio se basa en el caso de la ciudad de Barcelona que cuenta con una notoria tradición en la colaboración comunitaria entre entidades e instituciones educativas y sociales (Díaz-Gibson, Civís \& Longás, 2013; Ubieto, 2012). Se plantea una aproximación cualitativa a $30 \mathrm{RS}$ experimentadas en la ciudad, mediante un análisis de contenido en base a entrevistas realizadas a directores y otros profesionales socioeducativos con responsabilidades en el liderazgo y el gobierno de las mismas.

\section{Aproximación conceptual. El liderazgo en las Redes Socioeducativas}

Castiñeira (2011) y Coronel (2003) apuntan que en un contexto educativo las funciones de dirección, liderazgo y gestión, aunque puedan ir unidas a una misma persona son esencialmente distintas, cuestión que conviene distinguir para entender la naturaleza misma del liderazgo. La gestión comprende las competencias vinculadas a la gestión de personas, de presupuestos, de acciones, etc. a través de la planificación, organización, coordinación y toma de decisiones técnicas. La dirección implica mayor capacidad de toma de decisiones y la facultad para elaborar planes y diseñar estrategias con un margen de autonomía considerable. Sin embargo, liderar supone un escalón superior, más allá de gestionar y dirigir supone formular fines, trazar horizontes, dibujar un proyecto colectivo y guiar a los equipos a través de él. De este modo, el liderazgo implica el propósito conjunto y común de llevar a la práctica cambios reales en la organización, mientras que la gestión y la dirección implican la coordinación de los miembros y los recursos para desarrollar las actividades de la organización (Coronel, 2003).

Así, los cambios organizacionales alentados por el liderazgo de RS promueven la apertura de las fronteras institucionales a su entorno, en tanto que las RS son proyectos socioeducativos integrados por escuelas y entidades sociales y educativas de una misma comunidad. Específicamente, dichas escuelas y entidades desarrollan colaborativamente una programación y una acción estratégica conjunta orientada hacia el logro de metas comunes, como por ejemplo reducir el absentismo escolar, aumen- titutions (Díaz-Gibson, Civís, \& Longás, 2013; Ubieto, 2012). A qualitative approach to $30 \mathrm{ECNs}$ with experience in the city is proposed, through content analysis from interviews to head managers and other socio-educational professionals with responsibilities in leadership and governing.

\section{Conceptual Approach. Leadership in Educational Collaborative Networks}

Castiñeira (2011) and Coronel (2003) pointed that, in an educational context, the roles of direction, leadership and management, although they may be linked to a single person, are essentially different, which should be distinguished to understand the real nature of leadership. Management includes competences linked to managing people, budgets, actions, etc., through planning, organizing, coordinating, and making technical decisions. Direction involves a greater capacity to make decisions and the ability to develop plans and design strategies with a remarkable margin of autonomy. However, leadership implies a higher step, beyond managing and directing; it involves setting goals, describing horizons, drawing a group project, and guiding teams through it. In this way, leadership involves the joint and common purpose to carry out real changes in the organization, whereas management and direction involve the coordination of the members and resources to develop the activities of the organization (Coronel, 2003).

Thus, the organizational changes encouraged by ECN leadership promote the opening of institutional borders to their environment, as ECNs are socioeducational projects integrated by schools and social and educational entities in the same community. Particularly, these schools and entities collaboratively develop a programme and a joint strategic action aimed at achieving common goals, such as for example reducing school truancy, increasing educational success, improving the transition from school to work, or reducing child obesity, among others (DíazGibson et al., 2013). ECNs are characterized by an in- 
tar el éxito educativo, mejorar la transición escuelatrabajo o reducir la obesidad infantil, entre otras (Díaz-Gibson et al., 2013). Las RS se caracterizan por un intenso componente relacional entre actores, además de por un marcado acento en el liderazgo colaborativo de la acción. Las RS se han convertido en estrategias efectivas para optimizar los recursos de la comunidad, impactando así en la mejora educativa escolar y comunitaria (Carpenter et al., 2010; Renée \& McAllister, 2011).

A pesar de que existe poca literatura internacional en torno al liderazgo de RS, algunos estudios apuntan que el liderazgo de las relaciones intraescolares y el gobierno de los centros educativos conllevan diferencias importantes respecto al liderazgo de las relaciones extraescolares y el gobierno de RS (Carpenter et al., 2010; Daly, 2010). Si bien existe una regulación y una jerarquía determinada en las relaciones entre profesionales de la escuela, las relaciones entre organizaciones distintas de la comunidad carecen de normas y jerarquías explícitas (Díaz-Gibson \& Civís, 2011). La informalidad inicial de las relaciones extraescolares o comunitarias determina las acciones respecto a su propio liderazgo, así como a su propio gobierno. La colaboración incorpora una horizontalidad inherente entre los diferentes profesionales, donde nadie reúne un poder superior ni inferior a nadie (Díaz-Gibson \& Civís, 2011; Renée \& McAllister, 2011; Sorensen y Torfing, 2009).

Por otro lado, las perspectivas de liderazgo organizacional emergentes tienen en común una clara orientación relacional, que pretende ejercer el cambio a partir de potenciar las relaciones entre miembros, extender la influencia sobre el resto, compartir y distribuir el liderazgo, fomentando la aparición de líderes informales (Barnett \& McCormick, 2012; Longo, 2008; López \& Lavié, 2010; Bolívar et al., 2013). Así mismo, la literatura coincide en señalar que el liderazgo en entornos comunitarios e interorganizacionales demanda unas funciones específicas adecuadas a su realidad interactiva y colaborativa (Mandell \& Keast, 2009; Sorensen \& Torfing, 2009; Gordó, 2011). De esta manera, la no existencia de jerarquías verticales y la desregulación de las RS implican que un objetivo organizativo prioritario para su sostenibilidad sea la cohesión y la articulación. Saz y Ospina (2009) presentan tres acciones básicas en el liderazgo de RS compartidas tense relational component among actors, apart from a strong accent on the collaborative leadership of the action. ECNs have become effective strategies to optimize community resources, thus impacting on the school and community educational improvement (Carpenter et al., 2010; Renée \& McAllister, 2011).

Despite the fact that there is scarce international literature on the leadership of ECNs, some studies observe that the leadership of the intra-school relationships and governing of educational centres imply important differences in comparison to the leadership of extra-school relationships and governing a ECN (Carpenter et al., 2010; Daly, 2010). Although there is a regulation and certain hierarchy in the relationships among school professionals, the relationships between different community organizations lack explicit rules and hierarchies (Díaz-Gibson \& Civís, 2011). The initial informality of extra-school or community relationships determines the actions regarding their leadership, as well as their governing. Collaboration incorporates an inherent horizontality among the different professionals, where no-one has higher or inferior power than others (Díaz-Gibson \& Civís, 2011; Renée \& McAllister, 2011; Sorensen \& Torfing, 2009).

On the other hand, the emerging perspectives of organizational leadership have a clear relational orientation in common, which tries to exert change by promoting the relationships among members, extending the influence on the others, sharing and distributing leadership, promoting the emergence of informal leaders (Barnett \& McCormick, 2012; Longo, 2008; López \& Lavié, 2010; Bolívar et al., 2013). Likewise, literature coincides in pointing out that leadership in community and inter-organizational environments requires some specific functions particular to their interactive and collaborative reality (Mandell \& Keast, 2009; Sorensen \& Torfing, 2009; Gordó, 2011). In this sense, the lack of vertical hierarchies and the deregulation of ECNs involve that a priority organizational objective for their sustainability is cohesion and articulation. Saz and Ospina (2009) presented three basic actions in ECN leadership, coinciding with many previous studies: mediating between differences of members (bridging), promoting a common working culture (framing), and empowering members to lead actions (capacitating).

[ 64 ] JORDI DÍAZ-GIBSON, MIREIA CIVÍS ZARAGOZA, ELENA CARRILLO ÁLVAREZ Y MERITXELL CORTADA PUJOL SIPS - PEDAGOGIA SOCIAL. REVISTA INTERUNIVERSITARIA [1139-1723 (2015) 26, 59-83] TERCERA ÉPOCA 
por el grueso de la literatura: mediar entre las diferencias de los miembros (Bridging), promover una cultura de trabajo común (Framing) y capacitar a los miembros para liderar acciones (Capaciting). Éstas son claramente acciones que pretenden influenciar a los miembros de la red hacia la construcción de un proyecto organizativo y educativo común.

Por otro lado, un enfoque personalista respecto a la figura del líder de RS, es representado por Miller (2008) con la figura del -boundary spanner- o superador de fronteras, que dibuja un líder poseedor de conocimientos contextuales, habilidades sociales, conexiones y confianza, que está dispuesto a atajar los problemas sociales a través de la colaboración estratégica. Además, el rol del líder en las RS se basa en la habilidad para ser un process catalyst -o catalizador de procesos - (Mandell \& Keast, 2009), teniendo en cuenta las finalidades y actividades de la red, pero centrándose en el proceso como elemento crítico que conducirá a la construcción de una nueva globalidad, generando nuevas maneras de trabajar conjuntamente. En resumen, investigaciones recientes subrayan la importancia de las relaciones sociales, la democratización de la toma de decisiones, la colaboración interdisciplinar y la capacitación de los miembros para asumir cuotas de liderazgo.

\section{Estructuras de Gobernanza de las Redes Socioeducativas}

La literatura relaciona el gobierno de redes colaborativas a nivel comunitario con el concepto de gobernanza local, en tanto que la propia colaboración en red trasciende la jerarquía del gobierno y el gobernado (Navarro, 2002). La gobernanza de redes parte de la idea de que ningún actor local o comunitario por sí solo (público o privado) tiene en la actualidad ni el conocimiento ni la información suficientes para dar respuesta a los problemas socioeducativos de nuestras sociedades complejas (Kooiman, 2000; Longo, 2008; López \& Lavié, 2010). Esta concepción colaborativa de gobierno ya sea a nivel político, a nivel local o a nivel organizacional está emergiendo con fuerza en la última década (Sorensen y Torfing, 2009). A pesar de ello, existen pocos trabajos empíricos que profundicen en las estructuras necesarias para gobernar una RS hacia
These actions are clearly aimed at influencing the network members towards constructing a common organizational and educational project.

Furthermore, a personalistic approach to the figure of ECN leader is represented by Miller (2008) with the figure of the boundary spanner or the person who reaches across borders, who described a leader as possessing contextual knowledge, social skills, connections and confidence, who is willing to deal with social problems through strategic collaboration. Besides, the role of the leader in ECNs is based on the ability to be a process catalyst (Mandell \& Keast, 2009), considering the goals and activities of the network, but focusing on the process as a critical element that will lead to the construction of a new globality, generating new ways of working together. In summary, recent research highlights the importance of social relationships, the democratization of the decision-making process, interdisciplinary collaboration, and empowerment of members to take on leadership quotas.

\section{Governance Structures of Educational Collaborative Networks}

Literature relates governing of collaborative networks at a community level with the concept of local governance, as the networked collaboration itself transcends the hierarchy of government and governed (Navarro, 2002). Network governance springs form the idea that no local or community actor (public or private) on its own currently has either enough knowledge or information to give response to the socio-educational problems of our complex societies (Kooiman, 2000; Longo, 2008; López \& Lavié, 2010). This collaborative concept of governing, whether at a political, local or organizational level, has strongly emerged in the last decade (Sorensen \& Torfing, 2009). Despite this, there are few empirical studies that look into the structures needed to govern a ECN towards achieving proposed goals (Provan \& Kenis, 2007). This certainly is 
el logro de las metas planteadas (Provan \& Kenis, 2007). Éste es, sin duda, uno de los aspectos más importantes y complicados al mismo tiempo, en tanto que todas las RS deben pensarse a sí mismas y escoger una estructura de gobierno acorde a sus características, condiciones y recursos.

Provan y Kenis (2007) plantean tres modelos de gobernanza significativamente diferentes, $y$ añaden que cada uno de los modelos posee fortalezas y debilidades distintas que están ligadas al contexto donde desarrollan su acción, a la vez que producen resultados diferenciados tanto en los profesionales como en la comunidad. El primer modelo de gobernanza presentado es el de Participación compartida que es el más común y se caracteriza por ser los mismos miembros quienes se encargan del gobierno de la red. Las redes gobernadas bajo este modelo están considerablemente descentralizadas, en tanto que todos los miembros participan voluntaria y equitativamente en su gobierno. De este modo, ellos son los responsables de gestionar las relaciones internas y externas, los aspectos administrativos y la coordinación. Este tipo de gobernanza es común en redes del ámbito social, educativo y de salud principalmente por su capacidad para construir capital social en la comunidad (Chaskin, Brown, Venkatesh \& Vidal, 2001). Finalmente, los autores argumentan que este modelo de gobernanza es eficiente en redes con un bajo número de miembros y con relativa facilidad para alcanzar consensos.

Algunas de las dificultades generadas por la descentralización total pueden ser subsanadas con un segundo modelo de gobernanza más centralizado como el de Organización líder. Éste se da normalmente cuando una organización posee la legitimidad y los recursos necesarios para ejercer un rol de liderazgo en la red. La literatura nos muestra como en el ámbito social, educativo o de salud, la organización líder acostumbra a ser una institución con una posición central respecto a los recursos comunitarios y los usuarios (Provan \& Milward, 1995; Weiner \& Alexander, 1998). Bajo este modelo, las decisiones importantes y las actividades principales son coordinadas desde y por una organización líder, que de este modo asume unas cuotas de poder superior al resto de los miembros de la red, restando horizontalidad y discusión a la red. A su vez, ésta proporcionará el soporte administrativo y de ges- one of the most important and at the same time complex aspects, as all the ECNs have to think themselves and choose a governing structure in accordance to their characteristics, conditions and resources.

Provan and Kenis (2007) proposed three significantly different governance models, and added that every model has different strengths and weaknesses linked to the context where they develop their action, producing at the same time differentiated results both in professionals and the community. The first governance model is that of shared participation, which is the most common and is characterized by the members themselves being in charge of governing the network. Networks governed in this model are remarkably decentralized, as all the members participate voluntarily and equitably in the governance. In this sense, all of them are responsible for managing internal and external relationships, administration aspects, and coordination. This type of governance is common in social, educational and health networks mainly due to its capacity to construct social capital in the community (Chaskin, Brown, Venkatesh, \& Vidal, 2001). Finally, the authors considered that this governance model is efficient in networks with a low number of members and with relative easiness to reach agreements.

Some of the difficulties caused by total decentralization may be overcome with a second more centralized governance model such as a Lead organization. This model usually occurs when an organization has the legitimacy and necessary resources to exert a leading role in the network. Literature shows how in the social, educational and health fields, the lead organization is usually an institution with a central position regarding community resources and users (Provan \& Milward, 1995; Weiner \& Alexander, 1998). Within this model, important decisions and main activities are coordinated from and by a lead organization, which in this way assumes higher power quotas than the other network members, thus reducing horizontality and discussion in the network. In turn, it will provide administrative and management support needed to achieve the network's objectives, which will usually be quite near to the objectives of the same organization.

Moreover, a third governance model is that of

[ 66 ] JORDI DÍAZ-GIBSON, MIREIA CIVÍS ZARAGOZA, ELENA CARRILLO ÁLVAREZ Y MERITXELL CORTADA PUJOL SIPS - PEDAGOGIA SOCIAL. REVISTA INTERUNIVERSITARIA [1139-1723 (2015) 26, 59-83] TERCERA ÉPOCA 
tión necesario para alcanzar los objetivos de la red, que normalmente estarán muy cerca de los objetivos de la misma organización.

A su vez, un tercer modelo de gobernanza es el de Organización administrativa de la red. Este modelo se basa en la creación de una organización independiente del resto con el objetivo específico de gobernar la red y sus actividades. A pesar de que existe una alta interacción entre los miembros, el modelo centraliza sus relaciones a través de la organización administrativa, que juega un papel clave en la coordinación y dinamización de la red. Dicha organización está centrada exclusivamente en la gestión de la red y suele ser una entidad pública o una organización no gubernamental que trabaja en una comunidad concreta. La organización administrativa puede estar constituida por una sola persona (que se le denomina coordinador o facilitador), o puede ser una organización formal que consta de un director ejecutivo, personal y consejo que operan desde una oficina fiscal distinta (McEvily \& Zaheer 2004; Provan, Isett, \& Milward 2004). Este modelo generalmente acoge estructuras de toma de decisión en las cuales participan equitativamente los miembros de la red, donde se toman las decisiones técnicas y estratégicas, dejando las cuestiones operativas para la organización administrativa. Este modelo de gobernanza se usa para aumentar la legitimidad de la red, gestionando exclusivamente los procesos y problemas de la misma, e intentando reducir la complejidad del modelo de gobernanza de Participación compartida.

Así, se constata la necesidad de una concepción colaborativa del gobierno de las RS, la cual adopta distintos modelos más o menos centralizados en función de las propias características de las RS y su contexto.

\section{Método}

El presente estudio plantea un análisis de contenido de entrevistas realizadas a 30 profesionales experimentados en el liderazgo de RS que están colaborando en la mejora de los resultados educativos y sociales de diferentes comunidades en Barcelona, España. Barcelona cuenta con un importante número de asociaciones educativas y sociales del tercer sector, existiendo una entidad por cada 152 the Network administrative organization. This model is based on the creation of an organization independent from the others with the specific aim of governing the network and its activities. Despite there being a high interaction among the members, this model centralizes their relationships through the administrative organization, which has a key role in coordinating and sustaining the network. This organization is exclusively focused on managing the network and usually is a public body or non-governmental organization working in a certain community. The administrative organization can consist of one single person (who will be called coordinator or facilitator), or may be a formal organization consisting of an executive manager, staff and board operating from a different fiscal office (McEvily \& Zaheer, 2004; Provan, Isett, \& Milward, 2004). This model usually has decision-making structures with the equitable participation of all the network members, where technical and strategic decisions are made, leaving operational issues to the administrative organization. This governance model is used to increase the legitimacy of the network, by exclusively managing their processes and problems, and trying to reduce the complexity of the governance model of shared participation.

Thus, we observe the need for a collaborative concept of ECN governance, which adopts different more or less centralized models according to the characteristics of the ECNs and their context.

\section{Method}

This study proposes a content analysis of interviews carried out to 30 professionals with experience in leading ECNs that are collaborating to improve educational and social outcomes in different communities in Barcelona, Spain. Barcelona has a remarkable number of educational and social associations of the third sector, with there being one such entity per every 152 inhabitants. Moreover, the city has a long 
habitantes. Además, la ciudad tiene una larga tradición de colaboración público-privada respecto a temas educativos y sociales (Ubieto, 2012). El éxito de estas experiencias puede proporcionar información instructiva y relevante para el desarrollo y la mejora de otras RS en el país, así como para a orientar a profesionales del sector respecto a cómo liderar estrategias de colaboración entre la escuela y entidades sociales de la comunidad.

La investigación se basa en un enfoque constructivista y una concepción no modelada del conocimiento (Pérez, 2008), e investiga la construcción de la realidad hecha por los participantes (Guba \& Lincoln, 1994). El diseño de la investigación utiliza una metodología cualitativa y se centra en la comprensión y descripción de datos en lugar de, en su validación (O'Connor, Netting \& Thomas 2008). Específicamente se ha optado por la técnica de análisis de contenido entendida como el conjunto de procedimientos interpretativos de textos (escritos, visuales, orales,...) procedentes de procesos de comunicación previamente registrados. De este modo, el análisis nos permite mejorar la orientación discursiva de la investigación en su proceso de construcción de significado, a la vez que comprender en mayor profundidad las particularidades del liderazgo y el gobierno educativo en un contexto comunitario y colaborativo.

La selección de la muestra ha respondido al acercamiento intencional a casos de éxito de RS en la ciudad de Barcelona. De este modo, seleccionamos los 30 proyectos comunitarios socioeducativos, que responden a una estructura de RS definida con anterioridad, que habían sido previamente evaluados y reconocidos por el Instituto Municipal de Educación de Barcelona (IMEB) como prácticas de referencia, todas ellas con más de 5 años de experiencia en el territorio. Una vez identificados los programas, seleccionamos a un miembro del equipo de liderazgo de cada RS basándonos en dos criterios principales: haber formado parte del equipo de gestión y liderazgo desde los inicios de la RS, y representar a sus redes en el Área de educación del distrito. Concretamente, los 30 líderes que forman parte de la muestra final son directores de centros educativos, profesionales de servicios psicopedagógicos comunitarios, y gestores de programas socioeducativos comunitarios. tradition of public-private collaboration concerning educational and social issues (Ubieto, 2012). The success of these experiences may provide us with instructive and relevant information to develop and improve other ECNs in the country, as well as to guide professionals in this sector on how to lead coIlaboration strategies between the school and social entities in the community.

This research is based on a constructivist approach and a non-modelled concept of knowledge (Pérez, 2008), and looks into the construction of reality carried out by participants (Guba \& Lincoln, 1994). The research design uses a qualitative method and focuses on the comprehension and description data rather than on their validation (O'Connor, Netting, \& Thomas, 2008). Specifically, we opted for the content analysis technique understood as the set of text interpretation procedures (writings, visual, oral texts...) coming from previously recorded communication processes. In this way, the analysis allows us to improve the discursive orientation of this research in the process of meaning construction, and at the same time further understand the particularities of leadership and educational governance in a community and collaborative context.

The sample selection was the result of a purposeful approach to successful cases of ECNs in the city of Barcelona. In this way, we selected the 30 socio-educational community projects that meet a ECN structure as defined above, which had been previously assessed and recognized by the Municipal Institute of Education of Barcelona (IMEB) as experiences of reference, all of them with more than 5 years of experience in the country. Once the programmes were identified, we selected a member of the leadership teams in every ECN, on the basis of two main criteria: having been part of the management and leadership team since the beginning of the $\mathrm{ECN}$, and representing their networks in the Education Area of the district. Concretely, the 30 leaders that make up the final sample are head teachers of educational centres, professionals of community psychopedagogical services, and managers of community socio-educational programmes.

[ 68 ] JORDI DÍAZ-GIBSON, MIREIA CIVÍS ZARAGOZA, ELENA CARRILLO ÁLVAREZ Y MERITXELL CORTADA PUJOL SIPS - PEDAGOGIA SOCIAL. REVISTA INTERUNIVERSITARIA [1139-1723 (2015) 26, 59-83] TERCERA ÉPOCA 


\section{Procedimiento}

Se realizaron entrevistas semiestructuradas a cada uno de los 30 líderes que tenían como objetivo recoger información sobre el liderazgo y la gobernanza de las RS en cuestión. Concretamente, la entrevista constaba de dos preguntas abiertas: la primera profundizaba sobre el rol de liderazgo socioeducativo desempeñado, haciendo énfasis en las actividades clave de la acción de liderazgo en las RS; y la segunda se centraba en el modelo de organización de la RS, así como en los procesos llevados a cabo en la toma de decisiones para su gobierno. Las preguntas abiertas nos permitieron una mayor laxitud a la hora de explicar los procesos demandados, obteniendo así un discurso más contextualizado y abierto, propicio para el posterior análisis de contenido.

Los procedimientos para la recogida y análisis de datos se iniciaron con la transcripción completa y la creación de 30 documentos de texto. En la fase de análisis de contenido se procedió a la búsqueda de categorías e indicadores comunes entre los discursos de los diferentes líderes, dando respuesta sobre posibles modelos de éxito de liderazgo y gobernanza de RS. Con el objetivo de incrementar la consistencia del proceso de interpretación se llevaron a cabo dos niveles de análisis:

El primer nivel consistía en un análisis de contenido individual de todos los documentos llevados a cabo en paralelo por tres investigadores en el equipo. Para realizar el análisis de contenido se siguió el proceso de comparación constante, descubriendo qué categorías correspondían y encajaban mejor con los datos (Strauss, 2001). El análisis se llevó a cabo con el software informático ATLAS.ti 6.2 , concretando una codificación inicial con indicadores de análisis que fueron agrupados posteriormente en categorías, todas ellas organizadas en torno a los objetivos de investigación. Así, se contabilizaron las frecuencias en función de la aparición de cada indicador en las distintas redes, de modo que la frecuencia absoluta corresponde al número de RS que incorporan los indicadores y no al número total de veces que aparece la misma a través de los documentos. Un segundo nivel dirigido a garantizar la validez interna de la categorización resultante se basó en la comparación y discusión entre

\section{Procedure}

Semi-structured interviews were carried out with every one of the 30 leaders, with the aim of collecting information about leadership and governance of their ECNs. In particular, the interview consisted of two open questions: The first one was about the role of their socio-educational leadership, with emphasis on the key activities of the leadership action in the ECNs; and the second focused on the ECN organizational model, as well as on the decision-making processes concerning their governance. The fact that questions were open allowed us for greater laxity when explaining these processes, thus obtaining a more contextualized and open discourse, favourable for the posterior content analysis.

Procedures to collect and analyze data started with the full transcription and creation of 30 text documents. In the content analysis phase, we looked for common categories and indicators among the discourses of the different leaders, thus responding about possible successful models of ECN leadership and governance. With the aim of increasing the consistency of the interpretation process, two levels of analysis were conducted:

The first level consisted in an individual content analysis of all the documents carried out by three researchers of the team in parallel. To carry out this content analysis, the constant comparison process was followed, thus finding out what categories better corresponded to and fitted in with data (Strauss, 2001). The analysis was conducted with ATLAS.ti 6.2 software, with an initial coding with analysis indicators that were later grouped into categories, all of which were organized around the research objectives. Thus, frequencies in the presence of every indicator in the different networks were calculated, so the absolute frequency corresponds to the number of ECNs having the indicators rather than the total number of times that it appears in the documents. A second level aimed at guaranteeing internal validity of the resulting categorization was based on comparing and discussing among the three analyses carried out by each resear- 
los tres análisis efectuados por cada investigador, contrastando las categorías e indicadores, llegando a consensos como método propio del proceso de construcción de significado (Altheide et al., 2001).

\section{Resultados}

Los resultados del análisis de contenido muestran una matriz final compuesta por un total de 31 indicadores distribuidos en 7 categorías. Cinco de ellas están relacionados con las acciones de liderazgo específicas propias de un contexto interactivo-cola- cher, by contrasting categories and indicators, reaching agreements as the method particular to the meaning construction process (Altheide et al., 2001).

\section{Results}

The results of the content analysis show a final chart consisting of a total of 31 indicators arranged in 7 categories. Five of them are related to specific leadership actions particular to an interactive-collaborative context as that of $\mathrm{ECNs}$, and

Tabla 1. Frecuencia de indicadores sobre acciones de liderazgo

\begin{tabular}{|c|c|c|c|}
\hline Categorías & Indicadores & $\begin{array}{c}\text { Frecuencia } \\
\text { Absoluta }(n=30)\end{array}$ & $\begin{array}{l}\text { Frecuencia } \\
\text { Relativa }\end{array}$ \\
\hline \multirow{4}{*}{$\begin{array}{l}\text { Participación } \\
\text { en las } \\
\text { decisiones }\end{array}$} & Se realizan análisis de necesidades & 16 & $53,33 \%$ \\
\hline & $\begin{array}{l}\text { La toma de decisiones se realiza en base a la evaluación de las accio- } \\
\text { nes realizadas }\end{array}$ & 14 & $46,67 \%$ \\
\hline & La toma de decisiones se realiza de manera participativa & 26 & $86,67 \%$ \\
\hline & Se promueve la discusión participativa entre los agentes de la red & 15 & $50,00 \%$ \\
\hline \multirow{3}{*}{$\begin{array}{l}\text { Tareas } \\
\text { administrativas }\end{array}$} & Se promueve la búsqueda de recursos externos & 10 & $33,33 \%$ \\
\hline & Se realizan tareas de gestión de los recursos & 17 & $56,67 \%$ \\
\hline & Se realizan tareas de logística & 15 & $50,00 \%$ \\
\hline \multirow{4}{*}{$\begin{array}{l}\text { Tareas de } \\
\text { dinamización }\end{array}$} & Se promueven las sinergias entre los participantes & 23 & $76,67 \%$ \\
\hline & Se promueve la motivación entre los participantes & 11 & $36,67 \%$ \\
\hline & Se favorece la comunicación interna & 26 & $86,67 \%$ \\
\hline & Se realizan acciones de formación interna & 9 & $30,00 \%$ \\
\hline \multirow{4}{*}{$\begin{array}{l}\text { Fomento de } \\
\text { la unidad }\end{array}$} & Se promueve un sentimiento de compromiso compartido & 25 & $83,33 \%$ \\
\hline & Se promueve el reconocimiento de todos los participantes & 21 & $70,00 \%$ \\
\hline & Se fomenta un clima de confianza & 9 & $30,00 \%$ \\
\hline & Se fomenta un sentimiento de identidad y pertenencia & 24 & $80,00 \%$ \\
\hline \multirow{4}{*}{$\begin{array}{l}\text { Relación con } \\
\text { el entorno } \\
\text { comunitario }\end{array}$} & Se facilita la inclusión de entidades de la comunidad no participantes & 28 & $93,33 \%$ \\
\hline & Se realizan acciones de transferencia de conocimiento a la comunidad & 28 & $93,33 \%$ \\
\hline & Se dan situaciones de negociación entre políticos y técnicos & 12 & $40,00 \%$ \\
\hline & Se favorece la comunicación externa de la red & 20 & $66,67 \%$ \\
\hline
\end{tabular}

Fuente: Elaboración propia

[ 70 ] JORDI DÍAZ-GIBSON, MIREIA CIVÍS ZARAGOZA, ELENA CARRILLO ÁLVAREZ Y MERITXELL CORTADA PUJOL SIPS - PEDAGOGIA SOCIAL. REVISTA INTERUNIVERSITARIA [1139-1723 (2015) 26, 59-83] TERCERA ÉPOCA 
borativo como el de las RS, y las 2 siguientes hacen referencia a la estructura de gobernanza y los mecanismos de toma de decisiones colectivas a nivel comunitario.

De este modo, las 5 categorías inferidas respecto al liderazgo son: participación en las decisiones, tareas administrativas, tareas de dinamización, fomento de la unidad y relación con el entorno (Tabla I). Estas categorías explican las principales acciones conducidas por los líderes de RS para implementar estrategias educativas en colaboración con otros agentes de la comunidad: the other 2 refer to governance structure and collective decision-making mechanisms at a community level.

Thus, the 5 categories concerning leadership are: participation in decisions, administrative tasks, sustaining tasks, unity promotion, and relationship with environment (Table 1). These categories account for the main actions taken by ECN leaders to implement educational strategies in collaboration with other community agents:

TABLE 1. Frequency of indicators over leadership actions

Table 1. Frequency of indicators over leadership actions

\begin{tabular}{|c|c|c|c|}
\hline Categories & Indicators & $\begin{array}{c}\text { Absolute } \\
\text { Frequency }(n=30)\end{array}$ & $\begin{array}{l}\text { Relative } \\
\text { Frequency }\end{array}$ \\
\hline \multirow{4}{*}{$\begin{array}{l}\text { Participation } \\
\text { in decisions }\end{array}$} & Need analyses are conducted & 16 & $53.33 \%$ \\
\hline & Decision-making follows the assessment of actions carried out & 14 & $46.67 \%$ \\
\hline & Decision-making is carried out in a participative manner & 26 & $86.67 \%$ \\
\hline & Participative discussion is promoted among network agents & 15 & $50.00 \%$ \\
\hline \multirow{3}{*}{$\begin{array}{l}\text { Administrative } \\
\text { tasks }\end{array}$} & Search for external resources is promoted & 10 & $33.33 \%$ \\
\hline & Resource management tasks are carried out & 17 & $56.67 \%$ \\
\hline & Logistic tasks are carried out & 15 & $50.00 \%$ \\
\hline \multirow{4}{*}{$\begin{array}{l}\text { Sustaining } \\
\text { tasks }\end{array}$} & Synergies among participants are promoted & 23 & $76.67 \%$ \\
\hline & Motivation among participants is promoted & 11 & $36.67 \%$ \\
\hline & Internal communication is promoted & 26 & $86.67 \%$ \\
\hline & Internal training courses are carried out & 9 & $30.00 \%$ \\
\hline \multirow{4}{*}{$\begin{array}{l}\text { Unity promo- } \\
\text { tion }\end{array}$} & A feeling of shared commitment is promoted & 25 & $83.33 \%$ \\
\hline & The recognition of all participants is promoted & 21 & $70.00 \%$ \\
\hline & An atmosphere of trust is promoted & 9 & $30.00 \%$ \\
\hline & A feeling of identity and belonging is promoted & 24 & $80.00 \%$ \\
\hline \multirow{4}{*}{$\begin{array}{l}\text { Relationship } \\
\text { with commu- } \\
\text { nity environ- } \\
\text { ment }\end{array}$} & The inclusion of non-participating community entities is promoted & 28 & $93.33 \%$ \\
\hline & Actions to transfer knowledge to the community are carried out & 28 & $93.33 \%$ \\
\hline & $\begin{array}{l}\text { There are situations of negotiation between politicians and techni- } \\
\text { cians }\end{array}$ & 12 & $40.00 \%$ \\
\hline & External communication of the network is promoted & 20 & $66.67 \%$ \\
\hline
\end{tabular}

Source: Own elaboration. 
Los resultados del análisis muestran el fomento de la unidad como un indicador especialmente significativo. Ante un reto compartido donde diferentes organizaciones educativas colaboran con un mismo fin, los líderes afirman que es básico que todos encuentren el sentido a su implicación. Los líderes comparten ampliamente la necesidad de fomentar tanto un compromiso compartido -83\%, como un sentimiento de identidad y pertinencia -80\%-: "Todos los miembros reconocen que la Mesa de Educación está generando una identidad colectiva que nos enriquece a todos y da más fuerza a los planteamientos que se puedan hacer" (Fuente: Líder de una RS en Barcelona).

A su vez, los líderes destacan que en tanto que los diferentes profesionales trabajan normalmente dentro de sus organizaciones, no poseen el conocimiento necesario ni del profesional ni de su organización o el servicio, hecho que entraña ciertas dificultades a la hora de iniciar el trabajo conjunto. Éstos destacan un elemento clave en los procesos de colaboración como es la importancia de generar confianza entre el conjunto de los miembros, a través del reconocimiento de todos los agentes de la red -70\%- i (no es correcto)el fomento de un clima de confianza-30\%-: "En los inicios de la colaboración es importante dedicar tiempo a que todos nos conozcamos bien, tenemos comprobado que existen muchos prejuicios entre escuelas (y entidades) de una misma comunidad" (Fuente: Líder de una RS en Barcelona).

Además, la tabla I muestra el peso específico que tiene la participación en las decisiones para el conjunto de los 30 líderes. Cabe destacar en primer lugar la relevancia del liderazgo de la participación, dónde un 50\% sitúa la promoción de la discusión entre los agentes de la red como estrategia clave, y un $87 \%$ destacan que la toma de decisiones se realiza de manera participativa. En segundo lugar, son relevantes las alusiones sobre la evaluación como mecanismo de justificación de la toma de decisiones técnicas y estratégicas. En este sentido, un $53 \%$ de los líderes asienten que promueven la evaluación de necesidades en la comunidad, y un $47 \%$ que las decisiones generales se toman en base a las evaluaciones realizadas.

También, los líderes señalan holgadamente la importancia de buscar nuevas sinergias en la co-
The results of the analysis show that unity promotion is a particularly significant indicator. When facing a shared challenge with different educational organizations collaborating toward the same goal, leaders reported that it is essential that everyone finds sense to their involvement. Leaders fully share the need to promote both shared commitment -83\%- and a feeling of identity and belonging -80\%-. "All the members recognize that the Educational Board is creating a group identity that enriches us all and gives more strength to the approaches that may arise" (Source: Leader of a $\mathrm{ECN}$ in Barcelona).

Furthermore, leaders stand out that, as the different professionals usually work inside their organizations, they do not have enough knowledge of either the professional or organization or service, which implies certain difficulties when starting to work together. They highlight a key element in collaboration processes such as the importance of generating trust among the members by recognizing all the network agents -70\%- and promoting an atmosphere of trust -30\%-: "At the beginning of the collaboration, it is important to spend some time so that everyone gets to know each other; we certainly know that there are many prejudices among schools (and entities) in the same community" (Source: Leader of a ECN in Barcelona).

Besides, Table 1 shows the specific weight that participation in decisions has for the 30 leaders. We should firstly highlight the relevance of the leadership of participation, with 50\% placing promoting discussion among network agents as key strategy, and $87 \%$ standing out that decision making is carried out in a participative manner. Secondly, allusions to assessment as a mechanism to justify making technical and strategic decisions are relevant. In this respect, $53 \%$ of leaders admitted to promoting assessment of needs in the community, and $47 \%$ reported that general decisions are made according to the assessments carried out.

Moreover, leaders also point at the importance of looking for new synergies in the community, by attracting new agents interested in joining the cause to the collaborative project, facilitating the inclusion of non-participating agents -97\%-, apart

[ 72 ] JORDI DÍAZ-GIBSON, MIREIA CIVÍS ZARAGOZA, ELENA CARRILLO ÁLVAREZ Y MERITXELL CORTADA PUJOL 
munidad, atrayendo al proyecto colaborativo a nuevos agentes interesados en sumarse a la causa, facilitando la inclusión de agentes no participantes -97\%-, además de la transferencia de conocimiento a la comunidad -93\%-.

“Trabajamos para la conexión con otras entidades y proyectos del distrito como el Plan Educativo de Entorno (...) para conectar las escuelas de Verdum con todos los recursos posibles para hacer frente al fracaso escolar de los jóvenes (Fuente: Líder de una RS en Barcelona)".

Por otra parte, los resultados resaltan las tareas de dinamización de la RS como una acción destacada por los líderes. Son especialmente relevantes las acciones dirigidas a la promoción de las relaciones entre los miembros, generando flujos de interacción e intercambio como son la comunicación interna -87\%-, las sinergias $y$ colaboraciones -77\%- o las formaciones internas 30\%-: "Se intenta que la colaboración en red compense las limitaciones de cada entidad por sí sola (...) para eso hemos creado un espacio para el traspaso de información, apoyo y diálogo" (Fuente: Líder de una RS en Barcelona).

Finalmente, los líderes subrayan entre sus acciones ciertas labores de carácter administrativo como es la gestión de los recursos de la red -57\%, entre las que se encuentran la gestión de las reuniones y los grupos de trabajo, y específicamente tareas administrativas relacionadas con la logística -50\%-, en tanto que se hace necesario gestionar los diversos espacios para los continuos encuentros.

En relación al segundo objetivo (Tabla II), hemos inferido 2 categorías respecto a la gobernanza de estos procesos colaborativos que nos permiten agrupar los indicadores señalados por los líderes en su discurso; en primer lugar aquellos elementos referidos a los espacios para la toma de decisiones, y finalmente los elementos que profundizan en las particularidades del grupo motor. from the transfer of knowledge to the community $-93 \%$ -

"We work for the connection with other district entities and projects such as the Environment Educational Plan (...) to connect schools in Verdum with all the possible resources to tackle school failure of youth (Source: Leader of a ECN in Barcelona)".

Furthermore, results highlight ECN sustaining tasks as an action that leaders stand out. Particularly relevant are those actions aimed at promoting relationships among members, thus creating interaction and exchange flows such as internal communication -87\%-, synergies and collaborations $-77 \%$-, or internal training courses -30\%-. "The aim is that network collaboration can make up for the limitations of every entity on its own (...) that is why we created a space to transfer information, support, and dialogue" (Source: Leader of a ECN in Barcelona).

Finally, among their actions, leaders highlighted some tasks of an administrative nature such as managing network resources -57\%-, which includes managing meetings and working groups, and particularly administrative tasks related to logistics $-50 \%$-, as it is necessary to manage the different spaces for the continuous meetings.

With regard to the second objective (Table 2), we inferred 2 categories concerning the governance of these collaborative processes, which allow us to group those indicators reported by leaders in their discourse; firstly, those elements referring to spaces to make decisions, and finally those elements that give further detail of the particularities of the steering committee. 
Tabla 2. Frecuencias de indicadores sobre estructuras de la gobernanza

\begin{tabular}{|c|c|c|c|}
\hline Categorías & Indicadores & $\begin{array}{c}\text { Frecuencia } \\
\text { Absoluta }(n=30)\end{array}$ & $\begin{array}{l}\text { Frecuencia } \\
\text { Relativa (\%) }\end{array}$ \\
\hline \multirow{5}{*}{$\begin{array}{l}\text { Espacios para } \\
\text { la toma de } \\
\text { decisiones }\end{array}$} & Existe una asamblea general & 18 & 60,00 \\
\hline & Existe un comité técnico & 15 & 50,00 \\
\hline & Existe un comité ejecutivo & 12 & 40,00 \\
\hline & Existe un comité asesor & 3 & 10,00 \\
\hline & Hay una persona externa para la gestión administrativa & 4 & 13,33 \\
\hline \multirow{4}{*}{$\begin{array}{l}\text { Características } \\
\text { del grupo motor }\end{array}$} & El grupo motor está formado por representantes de cada entidad & 13 & 43,33 \\
\hline & El grupo motor se escoge por consenso & 6 & 20,00 \\
\hline & Una de las entidades de la red ejerce de grupo motor & 10 & 33,33 \\
\hline & $\begin{array}{l}\text { El grupo motor es representativo y además existe una entidad } \\
\text { ajena a la red que apoya sus funciones }\end{array}$ & 7 & 23,33 \\
\hline
\end{tabular}

Fuente: Elaboración propia

Table 2. Frequencies of indicators over governance structures

\begin{tabular}{|c|c|c|c|}
\hline Categories & Indicators & $\begin{array}{l}\text { Absolute } \\
\text { Frequency }(n=30)\end{array}$ & $\begin{array}{c}\text { Relative } \\
\text { Frequency (\%) }\end{array}$ \\
\hline \multirow{5}{*}{$\begin{array}{l}\text { Spaces to } \\
\text { make } \\
\text { decisions }\end{array}$} & There is a general assembly & 18 & 60.00 \\
\hline & There is a technical committee & 15 & 50.00 \\
\hline & There is an executive committee & 12 & 40.00 \\
\hline & There is an advisory board & 3 & 10.00 \\
\hline & There is an external person for administrative management & 4 & 13.33 \\
\hline \multirow{4}{*}{$\begin{array}{l}\text { Characteris- } \\
\text { tics of the } \\
\text { steering } \\
\text { committee }\end{array}$} & $\begin{array}{l}\text { The steering committee consists of representatives from every } \\
\text { entity }\end{array}$ & 13 & 43.33 \\
\hline & The steering committee is elected by general agreement & 6 & 20.00 \\
\hline & One of the entities of the network acts as steering committee & 10 & 33.33 \\
\hline & $\begin{array}{l}\text { The steering committee is representative and there is also an en- } \\
\text { tity outside the network that supports its functions }\end{array}$ & 7 & 23.33 \\
\hline
\end{tabular}

Source: Own elaboration.

Como podemos apreciar en la categoría espacios para la toma de decisiones, un indicador especialmente significativo es la existencia de una asamblea general. Dicha estructura ha sido nom-
As can be seen in the category spaces to make decisions, a particularly significant element is the existence of a general assembly. This structure was reported by $60 \%$ of leaders as a general organiza-

[ 74 ] JORDI DÍAZ-GIBSON, MIREIA CIVÍS ZARAGOZA, ELENA CARRILLO ÁLVAREZ Y MERITXELL CORTADA PUJOL SIPS - PEDAGOGIA SOCIAL. REVISTA INTERUNIVERSITARIA [1139-1723 (2015) 26, 59-83] TERCERA ÉPOCA 
brada por un 60\% de los líderes como estrategia organizativa general, independientemente del número de encuentros anuales que se realicen $u$ otras particularidades propias de cada red. Así, la asamblea general ha sido descrita como un espacio ampliamente participativo dónde se rinde cuentas y se aprueban prioridades de carácter global.

Además, en algunas de las redes analizadas encontramos otros órganos de gobernanza que tienen como objetivo agilizar los procesos de toma de decisiones, generalmente formados por un número más reducido de personas que desempañan funciones ejecutivas, como es el caso del comité técnico o el comité ejecutivo, o de apoyo o counseling en el caso del comité asesor.

El comité técnico está presente en el 50\% de las redes y responde a un espacio constituido por los representantes principales de cada entidad que conforma la RS, y en él se toman decisiones estratégicas, técnicas y ejecutivas de gran relevancia para el futuro del proyecto. Por otro lado, para hacer frente a las decisiones del día a día de cariz más administrativo o ejecutivo puntual, un $40 \%$ de las RS cuenta con un comité ejecutivo formado por entre dos y tres personas. Un porcentaje importante de líderes aseguran que el nombramiento de un comité ejecutivo-también denominado comité permanente- supone un plus de pragmatismo y agilidad a la acción global de la RS, en tanto que facilita la capacidad de reunión, de decisión y de ejecución:

"Nosotros somos una red de más de 15 entidades y se hace difícil y pesado reunirnos para cada decisión que debemos tomar (...) el comité ejecutivo se convoca de forma autónoma y actúa en base de los criterios establecidos por el comité técnico" (Fuente: Líder de una RS de Barcelona).

En cuanto a la composición del grupo motor, cabe destacar que un $66 \%$ de los líderes insisten en que el grupo que lidera el proyecto está compuesto por representantes de todas las entidades miembros de la RS. Este hecho, subraya la naturaleza particular propia de la gobernanza en contextos interactivos como las RS, señalando la importancia otorgada a la representatividad en la toma de decisiones. A su vez, en el $33 \%$ restante es una de las entidades quien lleva el peso del gobierno y la gestión de la red. tional strategy, regardless of the number of meetings per year or other particularities of every network. Thus, the general assembly was described as a widely participative space where accountability is present and global priorities are approved.

Moreover, in some of the networks under analysis, we found other governance bodies with the aim of speeding up decision-making processes, usually consisting of a lower number of people with executive functions, such as the case of the technical committee or the executive committee, or support or counselling functions as the advisory committee.

The technical committee is present in $50 \%$ of the networks, and is a space consisting of the main representatives of every entity making up the ECN, where strategic, technical, and executive decisions of great relevance for the project's future are made. On the other hand, to deal with daily decisions of a more administrative or exceptional executive nature, $40 \%$ of ECNs have an executive committee consisting of two or three people. A remarkable percentage of leaders stated that setting up an executive committee -also called permanent committeeimplies a plus of pragmatism and agility for the global action of the ECN, as it facilitates the capacity to meet, make decisions, and implement:

"We are a network of more than 15 entities, it is difficult and tiresome to meet for every decision to be made (...) the executive committee is called autonomously and acts according to the criteria established by the technical committee" (Source: Leader of a ECN in Barcelona).

As for the composition of the steering committee, it is outstanding that $66 \%$ of leaders insist that the group that leads the project consists of representatives of all the entities members of the ECN. This highlights the particular nature of governance in interactive contexts such as the ECNs, pointing at the importance given to representativeness when making decisions. In turn, in the other $33 \%$ it is one of the entities that is in charge of the governance and management of the network. 


\section{Discusión}

Los resultados confirman la singularidad de un enfoque de liderazgo educativo que trasciende las fronteras escolares (Huxham \& Vangen, 2000; Mandell \& Keast, 2009; Miller, 2008; Gordó, 2011), describiendo acciones que pueden orientar a los equipos directivos escolares hacia la mejora del impacto educativo mediante la colaboración con otros agentes de la comunidad. En este contexto, la informalidad de las relaciones entre los profesionales de las distintas instituciones participantes fundamenta un liderazgo basado en el fomento de dichas relaciones para generar unidad y confianza, así como en la facilitación de la toma de decisiones conjunta, promoviendo el consenso a la vez que la discusión para guiar los avances. Además, se constata la importancia del fomento del equilibrio entre representatividad y operatividad para la efectividad de los espacios de toma de decisiones colaborativas.

Los resultados muestran ampliamente la importancia que los líderes destinan a dinamizar las relaciones entre los profesionales de la RS, subrayando la promoción activa de la comunicación interna, la generación de oportunidades para compartir y colaborar, y la formación de los miembros. De este modo, el liderazgo se muestra como el responsable de la conexión cualitativa de los agentes de la comunidad tanto para un mejor funcionamiento global como para una mayor efectividad (Daly, 2010). Tal y como apuntan Moolenaar y Sleegers (2010), los recursos destinados a la interacción y la conexión entre los profesionales educativos generan conocimiento y capacidad de innovación educativa. En este sentido, se evidencian los esfuerzos de los líderes destinados a cohesionar unas relaciones especialmente diversas, lo que autores como Saz y Ospina (2009) conocen como framing. Una gran mayoría de los líderes destaca la importancia de fomentar la unidad y generar un clima de confianza entre los miembros de una estructura que carece de la formalidad a la que estamos acostumbrados. Las RS son altamente heterogéneas (Díaz-Gibson, et al., 2013; Saz \& Ospina, 2009) y aglutinan varios profesionales generalmente desconocidos, de disciplinas socioeducativas diversas y de instituciones diferentes. Las acciones apuntadas, tales como la promoción de un compromiso compartido, de un sentimiento de identidad o del

\section{Discussion}

Results confirm the uniqueness of an approach to educational leaderships that goes beyond the school borders (Huxham \& Vangen, 2000; Mandell \& Keast, 2009; Miller, 2008; Gordó, 2011), describing actions that may guide school managing teams to improve the educational impact through the collaboration with other community agents. In this context, the informality of the relationships among the professionals from the different participating institutions is the basis for a leadership based on the promotion of these relationships in order to create unity and trust, as well as on the facilitation of joint decision making, thus promoting agreement and discussion to guide advances. Moreover, promoting a balance between representativeness and operability for the effectiveness of collaborative decision-making spaces emerges as an important element.

Results clearly show the importance that leaders give to promoting relationships among the $\mathrm{ECN}$ professionals, highlighting the active promotion of internal communication, creation of opportunities to share and collaborate, and training of members. In this sense, leadership appears as responsible for the qualitative connection among the community agents both for a better global functioning and for greater effectiveness (Daly, 2010). As pointed by Moolenaar and Sleegers (2010), resources aimed the interaction and connection among educational professionals create knowledge and capacity of educational innovation. In this respect, we can see the efforts of leaders trying to unite some particularly diverse relationships, which such authors as Saz and Ospina (2009) know as framing. A great majority of leaders stands out the importance of promoting unity and creating an atmosphere of trust among the members of a structure that lacks this formality that we are used to. The ECNs are highly heterogeneous (Díaz-Gibson et al., 2013; Saz \& Ospina, 2009), and include diverse generally unknown professionals, from different socio-educational disciplines and different institutions. The aforementioned actions, such as promoting a shared commitment, a feeling of identity or the recognition among professionals, are evidence of the need to devote specific efforts and resources to unite the structure and activate the flows of communication and exchange

[ 76 ] JORDI DÍAZ-GIBSON, MIREIA CIVÍS ZARAGOZA, ELENA CARRILLO ÁLVAREZ Y MERITXELL CORTADA PUJOL SIPS - PEDAGOGIA SOCIAL. REVISTA INTERUNIVERSITARIA [1139-1723 (2015) 26, 59-83] TERCERA ÉPOCA 
reconocimiento entre profesionales constituyen una evidencia de la necesidad de destinar esfuerzos y recursos concretos para cohesionar la propia estructura y activar los flujos de comunicación e intercambio entre profesionales, promoviendo así procesos colaborativos paulatinamente.

También, los líderes otorgan una clara importancia a los procesos de evaluación para justificar la toma de decisiones de la red. De este modo, entendemos que la ausencia de jerarquías y la existencia de relaciones de poder equitativas requieren una justificación contrastada que secunde la toma de decisiones. En este sentido, los líderes de RS no tienen suficiente con su propio dominio profesional o experteza, ni con un amplio conocimiento contextual, ni tampoco con su capacidad de influencia en un contexto colaborativo determinado, tal como concluyen investigaciones previas (Miller, 2008). Es decir, el líder de RS además de estas capacidades necesita promover de forma activa una cultura evaluativa que ayude a tomar decisiones estratégicas sosteibles, contribuyendo a su vez a la mejora de la calidad de los procesos.

Por otro lado, si bien son mayoritarias las alusiones a la importancia de mediar y buscar consensos en la toma de decisiones en la red, es relevante como la mitad de los líderes comparten la idea de que para la generación de consensos es también necesaria la promoción de la discusión. Éste no es un hecho menor, en tanto que la óptica de un líder que busca consensos y otro que promueve la discusión para generar consensos es significativamente diferente. En este sentido, tal como apuntan Sorensen y Torfing (2011), la búsqueda de consensos per se puede conducir a decisiones simples y poco contrastadas; sin embargo, la dinamización activa de la discusión interdisciplinar es más susceptible de producir procesos y soluciones creativas. Así, entendemos que el hecho de que el líder promueva activamente la discusión para conseguir acuerdos es una manera brillante de sacar rendimiento al capital humano y social disponible, y por tanto una importante fuente de innovación colaborativa a nivel educativo.

Finalmente, cabe señalar que los resultados obtenidos no hacen alusiones relevantes entorno a acciones dirigidas a la distribución del liderazgo. Si bien un $86 \%$ de los líderes mencionan la participación como metodología habitual en la toma de decisio- among professionals, thus gradually promoting collaborative processes.

Likewise, leaders give clear significance to assessment processes to justify the network's decision making. Thus, we understand that the lack of hierarchies and the existence of equitable power relationships require a contrasted justification to back up decision making. In this respect, it is not enough for the ECN leaders to have professional command or expertise, or wide contextual knowledge, or their ability to influence on a certain collaborative context, as concluded by previous research (Miller, 2008). In other words, a ECN leader, besides having these capacities, has to actively promote an assessment culture that helps to make sustainable strategic decisions, thus contributing to improve the quality of processes.

On the other hand, although allusions to the importance of mediating and trying to find agreements when making decisions in the network are a majority, it is relevant how half the leaders share the idea that, to reach agreements, promoting discussions is also necessary. This is not a minor aspect, as the vision of a leader who tries to reach agreements and another who promotes discussions to reach agreements is significantly different. In this respect, as pointed by Sorensen and Torfing (2011), trying to reach agreements per se may lead to simple and not very contrasted decisions; however, the active promotion of interdisciplinary discussions is more likely to produce creative processes and solutions. Thus, we understand that the fact that the leader actively promotes discussion to reach agreements is a brilliant way of taking advantage of the human and social capital available, and therefore an important source of collaborative innovation at an educational level.

Finally, we should mention that results do not show relevant allusions to actions aimed at distributing leadership. Although $86 \%$ of leaders reported participation as the usual method when making decisions, and some of them stood out the importance of expanding responsibilities as a strategy to make professionals co-responsible, we found no indicators directly related to leadership distribution (Bryston \& Crosby, 1992; Saz \& Ospina, 2009; Stewart, 1997; Longo, 2008). In this respect, we understand that the set of actions that $\mathrm{ECN}$ leaders give priority 
nes, y algunos de ellos destacan la importancia de expandir responsabilidades como estrategia para corresponsabilizar a los profesionales, no encontramos indicadores directamente relacionados con la distribución del mismo (Bryston \& Crosby, 1992; Saz \& Ospina, 2009; Stewart, 1997; Longo, 2008). En este sentido, entendemos que el conjunto de las acciones priorizadas por los líderes de RS configuran un modelo de liderazgo más cercano al liderazgo relacional o catalizador de procesos de Mandell y Keast (2009), poniendo el énfasis en las relaciones como foco principal de la red, liderando procesos dirigidos a nutrir, inspirar y favorecer las interacciones, generando confianzas, sinergias y nuevas maneras de trabajar conjuntamente.

Por otro lado, en relación al segundo objetivo planteado respecto a la organización de los mecanismos de toma de decisiones colectivas, entendemos que los espacios diseñados para la toma de decisiones contribuyen a nutrir empíricamente la organización y la concreción de la gobernanza de RS. De este modo, se establece un embudo representativo que pretende articular las necesidades de representatividad con las de operatividad, concretando las decisiones de más generales a más específicas: la asamblea general se convierte en un espacio ampliamente participativo donde se aprueban las líneas generales de actuación; el comité técnico comprende un representante de cada entidad y discute cuestiones técnicas y estratégicas del proyecto, y el comité ejecutivo reúne a aquellos miembros más implicados en los objetivos de la red y conduce acciones operativas ya aprobadas.

Así mismo, cabe destacar que el análisis de contenido refleja claramente los 3 modelos de gobierno de redes desarrollados por Provan y Kenis (2007). De esta manera, el análisis confirma la teoría y da consistencia a dichos modelos en un ámbito socioeducativo. Así mismo, la estructura de gobernanza mayormente descrita por los líderes -con un $43,33 \%$ corresponde a un órgano de gobierno o grupo motor constituido por un miembro representante de las diferentes entidades que conforman la RS - el grupo motor está formado por representantes de cada entidad-, lo que Provan y Kenis (2007) conocen como el modelo de Participación compartida. A su vez, en un $33,33 \%$ de las redes analizadas es una de las entidades integrantes la que en mayor to shape a leadership model closer to the relational leadership or process catalyst by Mandell and Keast (2009), emphasizing relationships as the main focus of the network, leading processes aimed at nurturing, inspiring and enhancing interactions, generating trust, synergies, and new ways of working together.

On the other hand, and concerning the second objective about the organization of group collective decision-making mechanisms, we understand that the spaces designed for decision-making contribute to empirically nurture the organization and the concretion of ECN governance. In this respect, a representative funnel is established with the aim of assembling representativeness needs and operability needs, by specifying decisions from more general to more specific; the general assembly becomes a widely participative space where the main lines of action are approved; the technical committee consists of a representative per every entity, and they discuss technical and strategic issues of the project; and the executive committee gathers all those members with more involvement in the objectives, and leads already approved operational actions.

Likewise, we have to stand out that the content analysis clearly shows the 3 network governance models developed by Provan and Kenis (2007). In this respect, the analysis confirms the theory and gives consistency to these models in a socio-educational area. The governance structure most described by leaders $-43.33 \%$ - corresponds to a governing body or steering committee consisting of a representative from the different entities that make up the ECN - the steering committee consists of representatives from every entity -, which Provan and Kenis (2007) know as the Shared participation model. In turn, in $33.33 \%$ of networks under analysis, it is one of the member entities that mainly governs the network -one of the entities in the network acts as steering committee -, being the quarters for meetings and, in general, allocating some of its own resources to manage the ECN, which theory calls Lead organization. Thus, it is important to highlight that this organization does not always have a core position concerning community resources and users, as stated by Provan and Milward (1995) or Weiner

[ 78 ] JORDI DÍAZ-GIBSON, MIREIA CIVÍS ZARAGOZA, ELENA CARRILLO ÁLVAREZ Y MERITXELL CORTADA PUJOL SIPS - PEDAGOGIA SOCIAL. REVISTA INTERUNIVERSITARIA [1139-1723 (2015) 26, 59-83] TERCERA ÉPOCA 
medida gobierna la red-una de las entidades de la red ejerce de grupo motor-, sirviendo de base para los encuentros y generalmente, destinando recursos propios a la gestión de la RS, en lo que la teoría reconoce como Organización líder. Así, es importante reseñar que esta organización no siempre posee una posición central respecto a los recursos comunitarios y los usuarios, tal y como afirman Provan y Milward (1995) o Weiner y Alexander (1998), sino que a veces simplemente se trata de la persona - las personas más comprometidas con la acción colaborativa y comunitaria. Por último, un $23,33 \%$ de las redes recurre a un equipo de personas -entre una y tres- ajenas a la propia red para que asuman parte de las funciones de liderazgo -representado por la categoría del grupo motor es representativo y además existe una entidad ajena a la red que apoya sus funciones-y nombrado por Provan y Kenis (2007) como Organización administrativa de la red.

A pesar de este encaje, en el modelo Organización administrativa de la red encontramos tres variantes respecto a la procedencia de la o las personas que realizan el apoyo, siendo éstas: un miembro del equipo directivo de una escuela que dedica parte de sus labores a dicha causa, una entidad del tercer sector dedicada exclusivamente al proyecto, o un profesional contratado específicamente para realizar dichas funciones. Así mismo, podemos resumir que esta figura administrativa pretende en todo caso dar un apoyo de gestión al grupo motor y a los profesionales de la comunidad para facilitar el liderazgo técnico y compartido de la red. Sin duda, la presencia de una figura de soporte a la gestión puede maximizar la acción del equipo de liderazgo, liberando a los profesionales de tareas más administrativas y operativas que, tal y como muestran los resultados, son propias en las acciones de dichos líderes. Por tanto, la opción del soporte y promoción de la representatividad técnica de la RS se convierte en una pieza interesante para la operatividad y la efectividad del propio liderazgo, así como para la sostenibilidad de la RS.

\section{Conclusiones}

El presente artículo profundiza en el liderazgo de estrategias colaborativas en el ámbito escolar y educativo para gobernar de forma exitosa proyectos so- and Alexander (1998), but sometimes it is just the person or people most committed to the collaborative and community action. Finally, 23.33\% of networks resort to a team of people -between one to three- not members of the network so that they take on part of the leadership functions -represented by the category the steering committee is representative and besides there is an entity not belonging to the network that support its functions - and called by Provan and Kenis (2007) as Network administrative organization.

Despite this setup, in the model Network administrative organization we can see three variations depending on the origin of the person or persons providing support: a member of the managing team in a school that devotes part of his/her task to this cause, a third sector entity exclusively devoted to the project, or a professional specifically hired to develop these functions. Likewise, we can summarize that this administrative figure intends to give management support to the steering committee and the professionals in the community to facilitate technical and shared leadership in the network. Undoubtedly, the presence of a figure to support management can maximize the action of the leadership team, by releasing the professionals from more administrative and operational tasks that, as results show, are particular to these leaders' actions. Therefore, the option for support and promotion of ECN technical representativeness becomes an interesting element for the operability and effectiveness of leadership itself, as well as for the sustainability of the ECN.

\section{Conclusions}

This article goes further into the leadership of collaborative strategies in the school and educational area in order to successfully govern community-ba- 
cioeducativos de ámbito comunitario. De este modo, la optimización de los recursos de la comunidad y la mejora del impacto educativo pasan por el liderazgo y el gobierno adecuado de este tipo de iniciativas colaborativas. Así, las prioridades de los líderes se centran en la generación de confianza entre participantes, la conexión cualitativa de los profesionales y el fomento de la discusión y el consenso. Además, se destaca la necesidad de adoptar un modelo de gobernanza colaborativa adaptada a la realidad de la estrategia iniciada, que conjugue criterios de representatividad y operatividad al mismo tiempo.

Así mismo, entendemos que la aproximación presentada complementa y enriquece la función de liderazgo educativo en el contexto actual. Los resultados obtenidos muestran como la visión de la figura del líder o líderes va más allá de las propias fronteras escolares, proyectando una apertura organizacional hacia la generación de nuevos procesos de relación creativa con su entorno que buscan mejorar su impacto educativo. Finalmente, cabe resaltar que la contextualización del estudio se centra exclusivamente en la experiencia de RS de la ciudad de Barcelona. Este hecho, a pesar de ofrecernos una perspectiva detallada y en profundidad sobre buenas prácticas de liderazgo y gobierno de estrategias colaborativas a nivel comunitario, demanda una futura contrastación a nivel estatal e internacional con el objetivo de dar mayor validez al modelo presentado. Futuros estudios de caso nos pueden aportar una mayor profundidad respecto a la función de liderazgo educativo ante los retos de optimizar los recursos existentes y de generar sentido de proyecto conjunto en el contexto actual. sed socio-educational projects. In this respect, optimizing community resources and improving educational impact involve appropriate leadership and governance for this type of collaborative initiatives. Thus, the leaders' priorities focus on generating confidence among participants, qualitative connection of professionals, and promotion of discussion and agreement. Besides, there is the need to adopt a model of collaborative governance adjusted to the reality of the started strategy, which combines criteria of representativeness and operability at the same time.

Likewise, we understand that this approach complements and enriches the role of educational leadership in the current context. Our results show how the vision of the leader/leaders figure goes beyond the school borders, projecting an organizational openness towards generating new processes of creative relationship with their environment, which are aimed at improving their educational impact. Finally, we should emphasize that the contextualization of this study exclusively focuses on the ECN experience in the city of Barcelona. This fact, despite offering a detailed and deep perspective about good leadership and governance practices of collaborative strategies at a community level, requires further contrast at a national and international level with the aim of providing this model with greater validity. Further case studies can give us more details concerning the function of educational leadership in front of the challenges of optimizing existing resources and generating a sense of joint project in the current context. 


\section{Bibliografía / References}

Altheide, D., Gray, B., Janisch, R., Korbin, L., Maratea, R., Neil, D., ... Van Deman, F. (2001). News Constructions of Fear and Victim: An Exploration Through Triangulated Qualitative Document Analysis. Qualitative Inquiry, 7(3), 304-322.

Barnett, K. \& McCormick, J. (2012). Leadership and team dynamics in Senior executive leadership teams. Educational Management Administration \& Leadership, 40(6), 653-671.

Bolívar, A. (2010). Liderazgo para el aprendizaje. Organización y gestión educativa: Revista del Fórum Europeo de Administradores de la Educación, 18(1),15-20.

Bolívar, A., López-Yáñez, J. \& Murillo, F.J.(2013). Liderazgo en las instituciones educativas. Una revisión de líneas de Investigación. Revista Fuentes, 14, 15-60.

Bryson, J. M. \& Crosby, B. C. (1992). Leadership for the common good: Tackling public problems in a sharedpower world. San Francisco: Jossey-Bass.

Castiñeira, A. (2011). Prolegòmens al lideratge educatiu a Catalunya. Escola catalana, 46(468), 3-11.

Carpenter, H., Cummings, C., Dyson, A., Jones, L., Laing, K., Oseman, D., ... Todd, L. (2010). Extended services evaluation: End of year one report. Research report, DfE-RRo16. (London, DfE). Retrieved from: https://www.education.gov.uk/publications/eOrderingDownload/DFE-RRo16.pdf

Chaskin, R. J., Brown, P., Venkatesh, S., \& Vidal, A. (2001). Building Community Capacity. New York: Aline De Gruyter.

Coronel, J. M. (2003). Liderazgo y gestión en las organizaciones educativas: algunas tareas pendientes de resolver, algunas propuestas para desarrollar. Organización y gestión educativa: Revista del Fórum Europeo de Administradores de la Educación,17(6), 9-13.

Daly, A. (2010). Social network theory and educational change. Cambridge, MA: Harvard University Press.

Díaz-Gibson, J. \& Civís, M. (2011). Redes Socioeducativas promotoras de Capital Social en la comunidad: Un marco teórico de referencia. Cultura y Educación, 23(3), 415-429.

Díaz-Gibson, J., Civís, M. \& Longás, J. (2013) (en prensa). La Gobernanza de Redes Socioeducativas: claves para una gestión exitosa. Teoria de la Educación.

García, E. (2011). La planificación estratégica: una herramienta para hacer realidad el proyecto educativo, Aula de innovación educativa, 200, 61-66.

González, M. T. (2003). El liderazgo en tiempos de cambios y reformas. Organización y gestión educativa: Revista del Fórum Europeo de Administradores de la Educación, 71(6), 4-8.

Gordó, G. (2011). Lideratge i xarxes educatives. Escola catalana, (46)468, 23-27.

Guba, E. \& Lincoln, Y. (1994). Competing paradigms in qualitative research. In Denzin, N. K. y Lincoln, Y. S. (Eds.), Handbook of qualitative research (pp. 105-117). London: Sage.

Huxham, C., \& Vangen, S. (2000). Leadership in the shaping and implementation of collaboration agendas: How things happen in a (not quite) joined-up world. Academy of Management journal, 43(6), 1159-1175.

Kooiman, J. (2000). Societal governance: Levels, models, and orders of social-political interaction. Debating governance, 138, 66.

Longo, F. (2008). Liderazgo distribuido, un elemento crítico para promover la innovación. Capital humano: revista para la integración y desarrollo de los recursos humanos, 226, 84-91.

López, J. \& Lavié, J.M. (2010). Liderazgo para sostener procesos de innovación en la escuela. Profesorado. Revista de Currículum y Formación de Profesorado, 14(1), 71-92.

Mandell, M., \& Keast, R. (2009). A new look at leadership in collaborative networks: process catalysts. In Raffel, J., Leisink, P. Y Middlebrooks, A. (eds.), Public Sector Leadership: International Challenges and Perspectives (pp. 163-178). Cheltenham, UK: Edward Elgar

Mcevily, B., \& Zaheer,A. (2004). Architects of trust: The role of network facilitators in geographical clusters. In Kramer, R. \& Cook, K. (eds.), Trust and distrust in organizations (pp.189-213). New York: Russell Sage.

EL LIDERAZGO Y LA GOBERNANZA COLABORATIVA EN PROYECTOS EDUCATIVOS COMUNITARIOSIVA [ 81 ] SIPS - PEDAGOGIA SOCIAL. REVISTA INTERUNIVERSITARIA [1139-1723 (2015) 26, 59-83] TERCERA ÉPOCA 
Miller, P. (2008). Examining the work of boundary spanning leaders in community contexts. International Journal of leadership in Education, (17)4, 353-377.

Miller, P., Díaz-Gibson, J., Miller-Balslev, G., \& Scanlan, M. (2012). Looking beyond Harlem. International Insights for Area-based Initiatives. Middle School Journal, 44(1), 16-24.

Moolenaar, N., \& Sleegers, P. (2010). Social Networks, Trust and Innovation. How Social Relationships Supports Trust and Innovative Climates in Dutch Schools. In Daly A. J. (ed.) Social Network Theory and Educational Change (pp. 97-115). Cambridge: Harvard Education Press.

Ministerio de Educación. Instituto de Evaluación. (2010). PISA 2009 Programa para la Evaluación Internacional de Alumnos de la OCDE. Informe Español. Retrieved from: http://www.educacion.gob.es/dctm/ministerio/horizontales/prensa/notas/2010/20101207-pisa2009-informe-espanol.pdf?documentld=0901e72b8 O6ea35a

Murillo, F. J. (2006). Una dirección escolar para el cambio; del liderazgo transformacional al liderazgo distribuido. Revista Electrónica Iberoamericana sobre Calidad, Eficacia y Cambio en Educación, 4(4), 11-24.

Navarro, C. (2002, octubre). Gobernanza en el ámbito local. VII Congreso Internacional del CLAD sobre la Reforma del Estado y de la Administración Pública, Lisboa, Portugal.

O'Connor, M.K., Netting, F.E., \& Thomas, M.L. (2008). Grounded Theory: Managing the Challenge for Those Facing Institutional Review Board Oversight. Qualitative Inquiry, 14(1): 28-45.

Pérez Serrano, M. (2008). Inserción laboral de jóvenes con discapacidad. Análisis de las prácticas laborales, Pedagogía Social. Revista Interuniversitaria, 15, 99-110.

Provan, K. G., Isett, K. R., \& Milward, H. B. (2004). Cooperation and compromise: A network response to conflicting institutional pressures in community mental health, Nonprofit and Voluntary Sector Quarterly, 33(3), 489-514.

Provan, K., G. \& Kenis, P. (2007). Modes of Network Governance: Structure, Management, and Effectiveness, Journal of Public Administration Research and Theory, 18(2), 229-252.

Provan, K., \& Milward, B. (1995). A Preliminary Theory of Network Effectiveness: A Comparative Study of Four Mental Health Systems, Administrative Science Quarterly, 4O(1), 1-33.

Renée, M. \& McAlister, S. (2011). The Strengths and Challenges of Community Organizing as an Education Reform Strategy: What the Research Says. Recuperado de http://www.annenberginstitute.org/Products/coe.php

Saz, A., \& Ospina, S. M. (2009). The Work of Leadership in Formal Coalitions - Embracing Paradox for Collaboration. In Zwanenberg, Z. V. (ed.), Leadership in Social Care (pp. 103-128). London: Jessica Kingsley Publishers.

Sorensen, E., \& Torfing, J. (2009). Making Governance Networks effective and democratic through metagovernance, Public Administration, 87(2), 234-258.

Sorensen, E., \& Torfing, J. (2011). Enhancing Collaborative Innovation in the Public Sector: An Analytical Framework, Administration \& Society, 43(8), 842-868.

Stewart, M. (1997). Partnership and Power, European Journal of Work and Organizational Psychology, 6, 219225.

Strauss, A.L. (2001). Qualitative analysis for social scientists. Cambridge: Cambridge University Press.

Tough, P. (2008). Whatever it takes: Geoffrey Canada's quest to change Harlem and America. New York, NY: Houghton Mifflin Harcourt.

Ubieto, J. (2012). La construcción del caso en el Trabajo en Red. Teoría y práctica. Barcelona: Editorial UOC.

Weiner, B. J., \& Alexander, J. A. (1998). The Challenges of Governing Public-Private Community Health Partnerships, Health Care Management Review, 23(2), 39-55.

[ 82 ] JORDI DíAZ-GIBSON, MIREIA CIVÍS ZARAGOZA, ELENA CARRILLO ÁLVAREZ Y MERITXELL CORTADA PUJOL SIPS - PEDAGOGIA SOCIAL. REVISTA INTERUNIVERSITARIA [1139-1723 (2015) 26, 59-83] TERCERA ÉPOCA 
CÓMO CITAR ESTE ARTÍCULO / HOW TO CITE THE ARTICLE

Díaz-Gibson, J., Civís-Zargoza, M., Cortada-Pujol, M., \& Carrillo-Álvarez, E. (2015). El liderazgo y la gobernanza colaborativa en proyectos educativos comunitarios. Pedagogía Social. Revista Interuniversitaria, 26 59-83. DOI:10.7179/PSRI_2015.26.03

Fecha de recepción del artículo / received date: 2.VII.2014

Fecha de revisión del artículo / reviewed date: 8. VII.2014

Fecha de aceptación final / accepted date: 30.1X.2014

\section{DIRECCIÓN DE LOS AUTORES/ AUTHOR'S ADDRESS}

Jordi Díaz-Gibson: Facultad de Psicología, Ciencias de la Educación y del Deporte Blanquerna, Universitat Ramon Llull. Telf. 93.25330 o0. Dirección de correo/e-mail: jorgedg@blanquerna.url.edu

Mireia Civís Zaragoza. Dirección de correo/e-mail: mireiacz@blanquerna.url.edu

Meritxell Cortada Pujol. Dirección de correo/e-mail: meritxellcp@blanquerna.url.edu

Elena Carrillo Álvarez. Dirección de correo/e-mail: elenaca@blanquerna.url.edu

PERFIL ACADÉMICO / ACADEMIC PROFILE

Jordi Díaz-Gibson: Profesor Asociado. Departamento de Educación. FPCEE Blanquerna. Universidad Ramon Llull.

Mireia Civís Zaragoza. Doctora en Ciencias de la Educación. Profesora e investigadora en Facultad de Psicología, Ciencias de la Educación y del Deporte Blanquerna, Universitat Ramon Llull.

Meritxell Cortada Pujol. Profesora en Facultad de Educación, Traducción y Ciencias Humanas, Universitat de Vic.

Elena Carrillo Álvarez. Doctoranda en Facultad de Psicología, Ciencias de la Educación y del Deporte Blanquerna, Universitat Ramon Llull. 
